\title{
Financial Performance of Banks in India: A Study of Selected Private Sector Banks
}

\author{
Vasani Sureshbhai Vithalbhai ${ }^{1}$ \\ ${ }^{I}$ Research Scholar, Department of Commerce, Saurashtra University, India
}

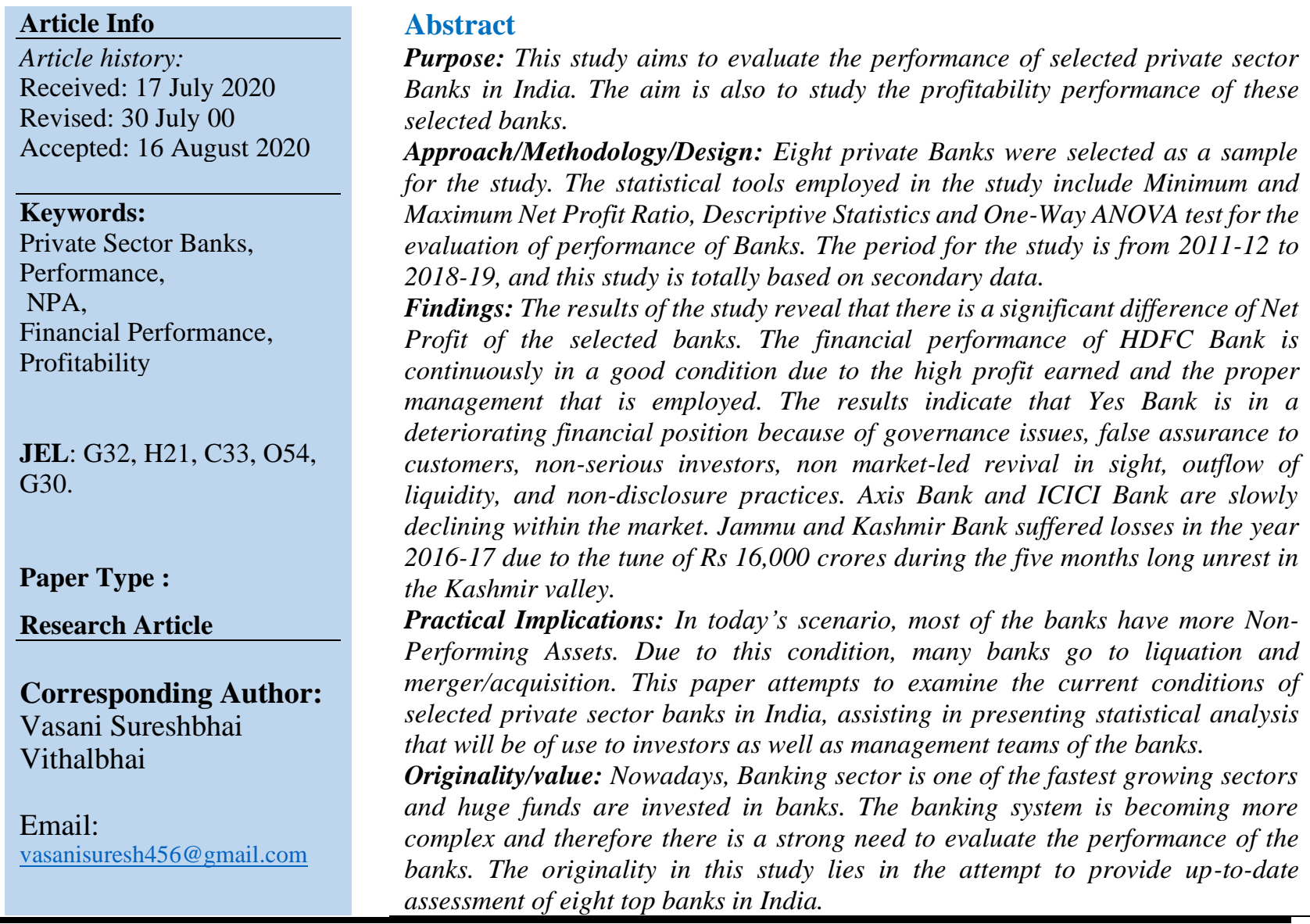

\section{Introduction}

Banks play a vital role in the Indian Economy because the banking industry handles finances in the country including cash and credit. The main function of the banks is to accept deposits from the public and grant credit to those who need some extra money for short-term as well as log-term requirement. The Indian banking system has moved a long way from a totally regulated environment to a deregulated market economy, even though there are many banks today merging and going bankrupt. The RBI is the highest banking regulatory body in India. It was established by the RBI Act, 1934 on $1^{\text {st }}$ April 1935. Before that time, banking was handled by three private sector banks which became Imperial Bank on the $1^{\text {st }}$ January 1949. In India, ten public sector banks were merged with four big public sector banks on $30^{\text {th }}$ August 2019. Now the public sector banks in India are only ten. Moreover, the number of private sector banks is reduced to twenty two. 
The banking sector plays an important role in efficient functioning of the economy of the country (Pinto, 2018). Comparing and evaluating the financial performance of financial institutions is a very important. However, fast and continuous changes in the global economic environment require more efforts and serious interest from concerned bodies. The growth of the banking sector in the country has also led to the development of several techniques for the measurement of the financial performance as well as the use of different parameters for evaluating the performance of banks.

The financial performance of a bank is not only important to the management of banks but also important for many stakeholders (Balaji, C., \& Kumar, G. P., 2016). Given this background, this study is an attempt to examine the financial performance of eight selected private banks in India. It provides up-to-date financial analysis about the performance of these selected banks in India, assisting in making decisions with regard to investment.

\section{Literature Review}

Several research studies are available, exploring different aspects of banking sector in India. However, there is still lack of up-to-date examination of financial performance of banks. This literature review charts out the most significant studies related to the topic of the present research article.

Nathwani (2004) in his doctoral work titled, "The Study of Financial Performance of Banking Sector of India", evaluated the financial performance of all the commercial banks of the country for the period of five years from 1997-1998 to 2001-2002. He tried to find out the different types of efficiency level of all the commercial banks in India. The study covered the evaluation of financial performance regarding profitability, credit efficiency, operational efficiency and productivity of banks using ten financial ratios. The study revealed that the operational efficiency in all the banking groups was significantly different during the study period. With regard to the overall profitability of Indian Banking Sector, there was a significant difference in performance in all the groups of banks during the study period.

Kavita Chavali and Kishan R. (2012) analysed the performance and profitability of public and private sector Banks. Six parameters were selected; Interest Income, Interest Expenditure, Spread, Net profit/Loss, Operating Profit/Loss Na Gross NPA as percentage of Total assets to analyse the performance and profitability of the Banks. For data analysis, SD, Coefficient of Variation, and Trend analysis were employed. The study period is from 2001 to 2008. The nmajor findings of this study show that the public sector banks were more profitable. It is also found out that high lending rate discourages new and credit worthily borrowers from seeking loans from banks (Chavali \& Kishan, 2012).

Sangmi, Mohi-ud-Din, and Tabassum Nazir (2010) studied on Financial Performance of Commercial Banks in India: Application of CAMEL Model. In this paper, five banks were selected on the basis of highest market capitalisation, and the period of the study is 2007 to 2010 . On the basis of CAMEL Model, the banks were ranked. According to the study results, the 1st Rank: HDFC

ISSN: $2708-9320$ (Print)

Copyright (C) 2020, Journal of Advanced Research in Economics and Administrative Sciences (JAREAS), Under the license CC BY 4.0 
Bank, $2^{\text {nd }}$ Rank: SBI, $3^{\text {rd }}$ Rank: Kotak Mahindra Bank, $4^{\text {th }}$ Rank: ICICI Bank, $5^{\text {th }}$ Rank: AXIS Bank. The analysis shows that banks with the highest capitalisation rates are ranked higher. However, further examination based on other parameters indicates that the financial performance of the same banks is not that good. Hence, it is concluded that there is no relation between market capitalisation and performance of the banks. (Sangmi, M., and Nazir. T., 2010).

Goyal and Kaur (2008) analyzed the performance of seven new private sector banks for the years 2001-07. Various statistical tools, such as SD, One Way ANOVA, and t-test were applied. In addition, various ratios were employed for the analysis of data. The results of the study indicate average debt/equity ratio at maximum levels in the case of Axis Bank, Kotak, and Mahindra Bank. Ratio of advances to total assets has shown an increasing trend for all the banks under study, indicating an increase in lending operations. The study also reported significant differences among the mean ratios of all parameters except for liquid assets to total assets, liquid assets to total deposits, net profit to average assets and percentage change in NPAs (Goyal \& Kaur., 2008).

Mittal and Pachauri (2013) studied on promotional tools and techniques adopted for retail banking, comparing the public sector banks and private sector banks. Their finding is that the perceptions of customers vary between public sector and private sector banks (Mittal \& Pachauri, 2013). In addition, Malhotra N. (2015) examined the financial soundness of the three banks; SBI, ICICI and Standard Bank. The study revealed that in terms of growth of assets, ICICI showed higher rates. The results indicate that SBI shows growth in advances and deposits, whereas Standard Charted Bank efficiently controls expenditure as well as income compared to the other banks. The study suggests that SBI has to improve its financial position to match with these two banks (Malhotra, 2015).

This review analysis reveals that there are many studies attempting to analyze the performance of banks in India. However, most of the studies reviewed in this article focused on comparing performance of banks in terms of total assets and Market Capitalization. There is no research on the study of mean differences in performance among the selected private sector banks.

\section{Methodology and Procedures}

The research design adopted for the study is experimental and descriptive. The data collected is based on secondary data. It is collected from annual reports of the banks and financial statements published from 2011 to 2019. Moreover, books, journal articles, thesis and data from the websites of the banks taken for the study and from Reserve Bank of India were used.

Eight private Banks were selected as a sample for study. These banks are: YES Bank, HDFC Bank, SIB Bank, Jammu \& Kashmir Bank, AXIS Bank, ICICI Bank, CUB Bank, IBL Bank. The method used for selecting these banks is simple random sampling. The statistical tools employed in the study include Minimum and Maximum Net Profit Ratio, Descriptive Statistics and One Way ANOVA test for the evaluation of performance of Banks. The period for the study is from 2011-12 to 2018-19, and this study is totally based on secondary data.

\section{Results and Discussion}


The following information is collected by the researcher from the Annual reports of the banks. Table No.1 shows the net profit ratios of all the banks under examinations.

Table 1: Net Profit Ratio (\%)

\begin{tabular}{|c|c|c|c|c|c|c|c|c|}
\hline \multirow{2}{*}{ YEAR } & \multicolumn{7}{|c|}{ COMPANY } \\
\cline { 2 - 9 } & YES B. & HDFC B. & SIB & J \&K B. & AXIS B. & ICICI B. & CUB & IBL \\
\hline $\mathbf{2 0 1 1 - 1 2}$ & 15.48 & 18.93 & 11.20 & 16.61 & 19.28 & 19.27 & 16.51 & 14.97 \\
\hline $\mathbf{2 0 1 2 - 1 3}$ & 15.68 & 19.18 & 11.32 & 17.19 & 19.05 & 20.77 & 14.71 & 15.19 \\
\hline $\mathbf{2 0 1 3 - 1 4}$ & 16.20 & 20.61 & 10.11 & 17.47 & 20.29 & 22.20 & 13.63 & 17.05 \\
\hline $\mathbf{2 0 1 4 - 1 5}$ & 17.32 & 21.07 & 3.59 & 7.20 & 20.73 & 22.76 & 14.63 & 18.05 \\
\hline $\mathbf{2 0 1 5 - 1 6}$ & 18.76 & 20.41 & 5.40 & 6.07 & 20.06 & 18.44 & 15.10 & 19.74 \\
\hline $\mathbf{2 0 1 6 - 1 7}$ & 20.27 & 20.99 & 6.71 & -24.41 & 8.26 & 18.09 & 15.84 & 19.90 \\
\hline $\mathbf{2 0 1 7 - 1 8}$ & 20.84 & 21.79 & 5.99 & 3.06 & 0.60 & 12.33 & 17.39 & 20.86 \\
\hline $\mathbf{2 0 1 8 - 1 9}$ & 5.80 & 21.29 & 5.81 & 6.05 & 8.50 & 5.30 & 18.12 & 14.82 \\
\hline Minimum & 5.80 & 18.93 & 3.59 & -24.41 & 0.60 & 5.30 & 13.63 & 14.82 \\
\hline Maximum & 20.84 & 21.79 & 11.32 & 17.47 & 20.73 & 22.76 & 18.12 & 20.86 \\
\hline Mean & 17.79 & 20.43 & 7.76 & 6.17 & 15.47 & 19.12 & 15.40 & 17.97 \\
\hline
\end{tabular}

Sources: Annual Report of the Company

Chart 1: Net Profit Ratio

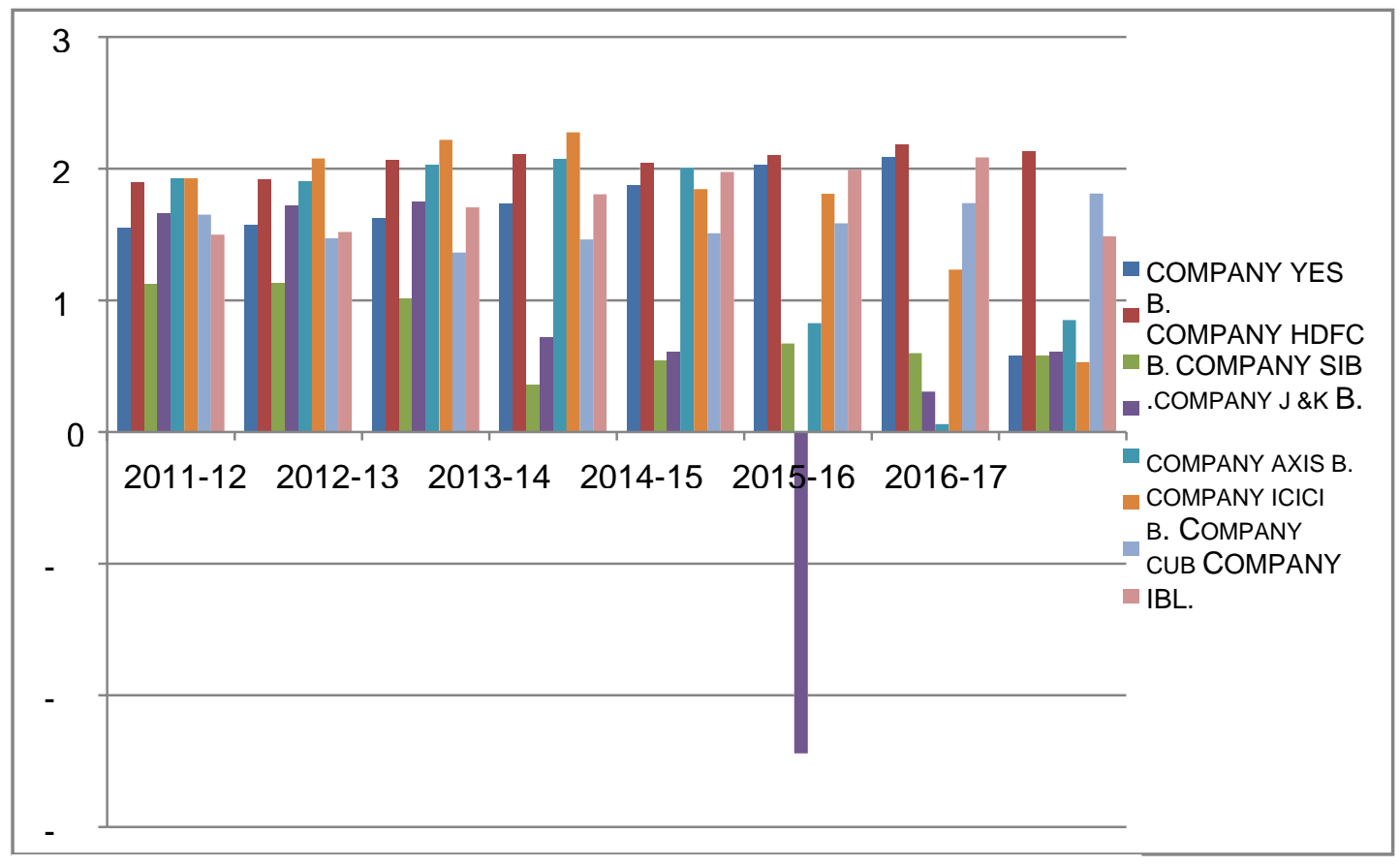

Sources: Annual Report of the Company 
Table no. 1 shows the net profit of the selected eight private banks in India. The above ratio is for five years from 2011-12 to 2018-19. The NP of Yes Bank is the highest in the year 2017-18 which is $20.84 \%$ and the lowest in the year 2018-19 which was only $5.80 \%$. In the other years, net profit ratio of Yes Bank fluctuated.

The profit of the HDFC bank is $21.79 \%$ in the year 2017-18 and the lowest in the year is $18.93 \%$. It means the performance of the HDFC was good. The profit of SIB is very low in the selected sample of the study. In the year 2013-14, it was $17.47 \%$. The one year profit of the Jammu \& Kashmir Bank was very low -24.41. It means the banks reported loss in that year. The profit of the Jammu \& Kashmir bank is fluctuated during the selected study period.

As the table above shows, the profit of Axis Bank was higher in the starting year but then it declined year by year. The profit of Axis Bank was in the year 2017-18 only $0.60 \%$. The profit of the ICICI was good during the study period but it is in a decreasing trend. The profit of the CUB bank is good. The bank is performing well in the market because this bank profit was not highly fluctuated. It can be stated that the bank has a good position in the market. The profit of the IBL bank was also good. The bank is performing well in the market with the highest profit in 2017-18 (20.86\%) and the lowest in the year 2018-19.

Table 2: Descriptive Statistics Result

\begin{tabular}{|c|c|c|c|c|c|c|c|c|}
\hline \multicolumn{9}{|c|}{ Net Profit } \\
\hline \multirow{2}{*}{ Name of Banks } & \multirow{2}{*}{$\mathbf{N}$} & \multirow{2}{*}{ Mean } & \multirow{2}{*}{$\begin{array}{c}\text { Std. } \\
\text { Deviation }\end{array}$} & \multirow{2}{*}{$\begin{array}{l}\text { Std. } \\
\text { Error }\end{array}$} & \multicolumn{2}{|c|}{$\begin{array}{l}\text { 95\% Confidence } \\
\text { Interval for Mean }\end{array}$} & \multirow{2}{*}{ Min } & \multirow{2}{*}{$\operatorname{Max}$} \\
\hline & & & & & $\begin{array}{l}\text { Lower } \\
\text { Bound }\end{array}$ & $\begin{array}{l}\text { Upper } \\
\text { Bound }\end{array}$ & & \\
\hline Yes bank & 8 & 16.29 & 4.70 & 1.66 & 12.36 & 20.23 & 5.80 & 20.84 \\
\hline HDFC Bank & 8 & 20.66 & 1.05 & 0.37 & 19.78 & 21.54 & 18.93 & 21.79 \\
\hline $\begin{array}{l}\text { South Indian } \\
\text { Bank }\end{array}$ & 8 & 7.52 & 2.94 & 1.04 & 5.06 & 9.98 & 3.59 & 11.32 \\
\hline J \& k bank & 8 & 12.26 & 7.61 & 2.69 & 5.90 & 18.62 & 3.06 & 24.41 \\
\hline Axis bank & 8 & 14.60 & 7.70 & 2.72 & 8.16 & 21.03 & 0.60 & 20.73 \\
\hline ICICI Bank & 8 & 17.40 & 5.86 & 2.07 & 12.50 & 22.29 & 5.30 & 22.76 \\
\hline
\end{tabular}




\begin{tabular}{|l|c|c|c|c|c|c|c|c|}
\hline $\begin{array}{l}\text { City Union } \\
\text { Bank }\end{array}$ & 8 & 15.74 & 1.52 & 0.54 & 14.47 & 17.01 & 13.63 & 18.12 \\
\hline $\begin{array}{l}\text { Indusind bank } \\
\text { Itd }\end{array}$ & 8 & 17.57 & 2.43 & 0.86 & 15.54 & 19.61 & 14.82 & 20.86 \\
\hline Total & 64 & 15.25 & 5.93 & 0.74 & 13.77 & 16.74 & 0.60 & 24.41 \\
\hline
\end{tabular}

Sources: Annual Report of the Company

Table 3: Calculation of ANOVA

\begin{tabular}{|c|c|c|c|c|l|}
\hline \multicolumn{7}{|c|}{ ANOVA } \\
\hline NP & Sum of Squares & df & Mean Square & F & Sig. \\
\hline Between Groups & 878.188 & 7 & 125.46 & 5.24 & 0.00 \\
\hline Within Groups & 1340.91 & 56 & 23.945 & & \\
\hline Total & 2219.1 & 63 & & & \\
\hline
\end{tabular}

Sources: Annual Report of the Company

The above ANOVA table indicates that the significance value is less than the $0.05 \%$. Hence, $\mathrm{H}_{0}$ (Null hypothesis) fails to be accepted at a level of 5\%. The results show that there is a significant difference of net profit of the selected banks in India. As the tables present, Jammu and Kashmir Bank suffered losses in the year 2016-17 due to the tune of Rs 16,000 crore during the five months long unrest in the Kashmir valley. In addition, due to the complete halt of economic activity, the bank suffered loss of property worth crores of rupees. Similarly, Yes Bank collapsed due to deteriorating financial position, Governance Issue, False Assurance to customers, non-serious investors, non-market-led revival in sight, outflow of liquidity and due to non-disclosure practices.

The performance of the HDFC Bank is continuously in good condition because of high profit earned and the management of the bank is proper. Net profit of SIB Bank is very low and slow. The bank is growing very slowly. Therefore, it has not seen any effect on the market. Axis Bank and ICICI Bank are slowly declining within the market. Subsequently, investors should not invest within these Banks. The performances of the other banks investigated in this study show constant fluctuation during the study period. From the above analysis, all Banks have different Net profit ratio during the study period. Accordingly, in all the cases the Null hypotheses is rejected. It can be concluded that there is a significant difference between the profits of the selected banks during the period of the study. 


\section{Conclusion and Suggestion}

The present study aimed at analyzing the financial performance of YES Bank, HDFC Bank, SIB Bank, Jammu \& Kashmir Bank, AXIS Bank, ICICI Bank, CUB Bank, IBL Bank. The results of the study reveal that there is a significant difference of Net Profit of the selected banks. The financial performance of HDFC Bank is continuously in good condition due to profit and proper management. The results indicate that Yes Bank is in deteriorating financial position because of governance issue, false assurance to customers, Non-serious investors, Non market-led revival in sight, outflow of liquidity, and Non-Disclosure practices. Axis Bank and ICICI Bank are slowly declining within the market. Jammu and Kashmir Bank suffered losses in the year 2016-17 due to the tune of Rs 16,000 crore during the five months long unrest in the Kashmir valley.

The data, which is used for this study, is based on the annual report of the banks and secondary data collected from RBI \& IBA Bulletin. Therefore, the quality of this research paper depends on quality and reliability of data published in the annual reports of the selected banks. The study is confined to five years data only from 2011-12 to 2018-19. Detailed analysis covering a lengthy period, which may give slightly different results, has not been made.

\section{Conflict of Interest}

The author of the article declares no conflict of interest.

\section{Funding}

This research study was not funded by any institution. The author conducted the study on his own expenses.

\section{References}

Balaji, C., \& Kumar, G. P. (2016). A Comparative Study on Financial Performance of Selected Public \& Private Sector Banks in India. Journal of Commerce and Trade, 11(2), 89-96.

Chavali, K., \& Rao, K. (2012). Performance and profitability of public and private sector banks-An empirical analysis. Asian Journal of Research in Banking and Finance, 2(2), 38-51.

Goyal R.,\& Kaur R. (2008). Performance of New Private Sector Banks in India. International Journal of Data and Network security , 1-11.

Malhotra, N. (2015). Standard Chartered Bank, ICICI and SBI-A Comparative Analysis in Post Reforms Scenario. EXCEL International Journal of Multidisciplinary Management Studies, 5(10), 15-20. 
Mittal, S., \& Pachauri, K. K. (2013). A Comparative Analysis of Promotional Tools \& Techniques Adopted For Retail Banking In Public Sector and Private Sector Banks. Journal of Business Management \& Social Sciences Research (JBM\&SSR), 2(2), 83-88.

Nathwani, N. (2004). The Study of Financial Performance of Banking Sector of India (Doctoral dissertation, Saurashtra University).

Pinto, O. R., \& Al-Shawesh, M. M. H. A(2018). Financial Performance of Private Sector Banks With Reference to ICICI Bank And Selected Private Banks.

Sangmi, M. U. D., \& Nazir, T. (2010). Analyzing financial performance of commercial banks in India: Application of CAMEL model. Pakistan Journal of Commerce and Social Sciences (PJCSS), 4(1), 40-55. 